
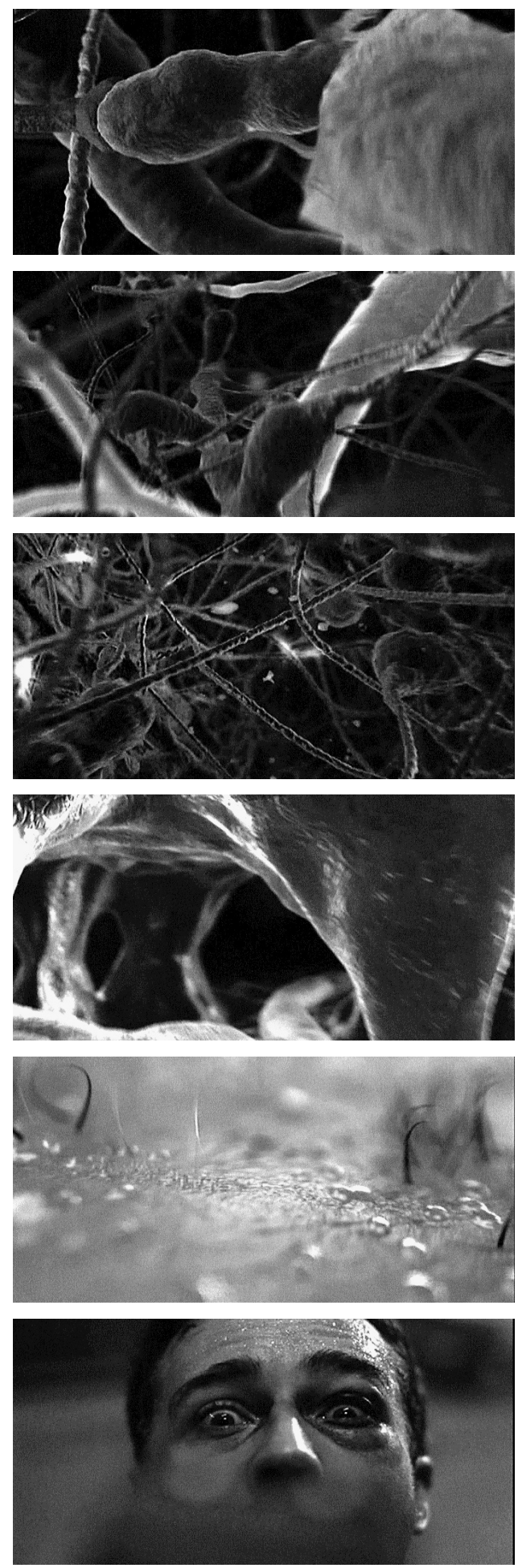

Fight Club. Dir. David Fincher, 1999. Stills. 


\section{A Theory of Animation: Cells, L-systems, and Fillm}

\section{CHRISTOPHER KELTY AND HANNAH LANDECKER}

Somehow I too must come to make things; not plastic, but written things-realities that emerge from handwork. Somehow I too must discover the smallest basic element, the cell of my art, the tangible immaterial means of representation for everything . .

—Rainer Maria Rilke, letter to Lou Andreas-Salomé, $1903^{1}$

David Fincher's 1999 Gnostic multiple-personality conspiracy epic Fight Club opens with cells. The sequence is a "night dive" fly-through of the protagonist's brain. It begins at a magnification of some 150,000x and zooms out-magnification decreasing - through the structure of a nerve cell, the folds of the brain, vessels, sinuses, the skull and skin, and up the barrel of a gun pointed at the head, or, if you like, at the nerve cell from which we have just been flown.

The sequence was made by Kevin Mack, a computer graphics specialist and self-described “amateur neurologist," and Katherine Jones, a medical illustrator and a participant in the Visible Human Project. Jones storyboarded a ride through the brain starting in the center of "fearful thought"- the amygdala-and out to the skin and forehead of actor Edward Norton. Just as striking as this visual representation of brain cells is what Mack says of his creation:

The most interesting aspect of what we did, was the fact that we grew the neurons. Rather than having artists spend months modeling these very complex organic forms, we used L-Systems to grow them. L-Systems are a formal grammar for defining branching structures, primarily for defining the structure of plants, it was come up with by a botanist named Aristid Lindenmayer, and it was cool because we were actually growing a brain and while it wasn't a functional brain, you know, that's just the next step. ${ }^{2}$

Mack makes the incredible claim that what can be seen on screen is not a representation of a brain, it is a brain. Mack-in a manner that is not simply naiveactually believes that something in this image is alive, that it is a vegetable, if not a human brain. One might say that Mack mistakes the product of his animation software for the real biological brain it is meant to represent, but what kind of 
"mistake" is this? It is one that Mack is most definitely not alone in making when it comes to life and software. Contemporary film, art, and architecture are replete with biologically inflected forms: L-systems, cellular automata, and genetic algorithms are used to create (among other things) the complex forests, photorealistic skin and hair, and lively and deadly animated crowds that are now regular features of software packages such as Alias Wavefront's "Maya” or Softimage's "Behavior." As fast as Hollywood can imagine a computer graphics innovation like rapid brain fly-throughs and fell orcs in battle, such software packages incorporate them as plug-ins, add-ons, and spin-offs.

What, in these examples, does animation software animate? A first temptation might be to think of such tools as built around biological metaphors in which the image or the process of creating an image is understood through its apparent likeness to some biological object or process-often enthusiastically embraced precisely for its "realism." However, this is a comparison of appearances that belies the conditions by which such images can be seen, understood, and believed to be alive. For example, the Fight Club image created with L-systems bears a direct relation to both a particular technique of animating formal grammars and a history of attempts to model the basic developmental patterns of plant growth by cell division. This image of the brain is neither a magnification nor an illustration, but a complete de novo construction of an image "grown" from an analytic theory of botany, cellularity, and time. It is not a simulation of cells; it is an animation of a theory of cellular life.

What interests us here is not the status of these images of life in relation to the real-some ontological existent to which they do or do not correspond as lifelike-but their status as images in relation to knowledge; in particular, in relation to the systematized knowledge of the biological sciences of the nineteenth and twentieth century. It is no more a mistake or illusion for Mack to see life in his animations than it was for the botanist Aristid Lindenmayer to see life in his theory, for in these images the "life" constantly produced by practices of theory, observation, modeling, and representation in life science is set into motion.

Analysis of animation, in software or other media, must be connected to the broader question of how images of life exist in relation to knowledge production in the life sciences. To that end, this paper undertakes a "media archeology" that bookends the twentieth century. At one end is the use of microcinematography to capture living cells on film in the laboratories of the early twentieth century; at the other is the development of L-systems to describe cellular biological development and the transformation of that development into computer graphics animations. Both examples are concerned with the scientific theory of living things, 
with "life-as-animation," as well as the technical animation (on a screen) of particular living things. Both engage scientific theories as they render new images on a screen. Via these specific examples we situate contemporary animation in a genealogy of the visualization of life that is a helix of the perceptible and the intelligible-a helix with human-embodied perception as one strand and the abstractions of formal, mathematical symbols and diagrams as the other.

This focus on microcinematography and L-systems is only one example of the relation of perceptibility and intelligibility. Other examples are entirely possible, but this example reflects our particular concern with cells (as opposed to genes, DNA, organismal form, or evolutionary theory—all of which also lay claim to the concept of life). Cell films and L-systems are connected not just as attempts to see life but by the object and the concept of the cell, that "tangible immaterial means of representation" of life. Time-lapse microcinematography was seen from its outset in 1907 as a way of both proving cell theory and further investigating its implications. Nineteenth-century cell theory proposed that all cells arose from other cells and that all organisms were nothing but congeries of cells. It connected cell theory directly to the fundamental formal problem of the continuous and the discrete-How does one original egg cell, during embryo development, become many cells but one organism, then in turn via sexual reproduction become one egg cell again? Cell theory meant the cell was the seat of both reproduction and heredity, of individuality and dividuality, of life and its extension over time. ${ }^{3}$ Later, L-systems were conceived and built with the cellularity exhibited by microcinematography; although a mathematical formalization, L-systems too, confronted the problem of the continuous and the discrete via its core assumption about the growth of plants: that development proceeds by and through the cellular components of living organisms. ${ }^{4}$

Biological science and media theory are rarely thought through together, despite the obvious flourishing of biologism and developmental thinking in realms of representation far afield from the laboratory. This article bridges the fields of media theory and science studies by demonstrating how, on the one hand life science is conducted and pursued through its media of representation and how, on the other, some kinds of popular media more generally come to have scientific knowledge built into them. For media theorists this article is a challenge to pursue greater technical and scientific familiarity with new media as a necessary part of their critical repertoire; for scholars in science studies, it offers further evidence of the intricate relationship between knowledge production and representation. ${ }^{5}$ However, it is an assumption inherent in our approach that there is no "direction of influence" between the realms of science and spectacle. We 
employ the method of media archeology to trace how, in practice, both images and theories are transported between these realms and help constitute them as such.

Gilles Deleuze's Cinema books have shown how "aesthetic, philosophical, and scientific modes of understanding converge in producing cultural strategies for imagining and imaging the world." Beyond this is a domain of historical and technical specificity that adds to those modes of understanding and their particular convergence in cultural strategies for imagining and imaging the living world. ${ }^{6}$ This direct and admittedly complicated engagement with historical and technical detail is offered not just for its own sake but as a critique of euphoric "lift-off" narratives of new media which focus on the radical difference of analog from digital representation-narratives that offer the putative loss of a direct, material referent in favor of image creation via "pure" numerical manipulation as an adequate means to characterize new media. In the Fight Club opening sequence, for example, the images are not bound by, and in fact bear little relation to, the existence of Edward Norton's actual pro-filmic amygdala. And while it is certainly the case that these images necessarily exist through mathematics and computing, to refer to such images as "virtual" or "pure simulacra" is to renounce any critical understanding of the mathematics, software, or computing machines' real existence, leaving us with only the mesmerizing dance of images on a decontextualized screen.

These images are not based in any old mathematics or technology whatsoever. The axis of analysis that relies on the dichotomies of virtual and real or digital and analog gives no specificity to the mathematical forms and time-based computing media that subtend these beautiful neurons. To ignore these specifics is to lose sight of what might be understood as the helix of observation, formalization, and interpretation that has established the conditions for how we are able to see life today.

\section{Part 1: Microcinematography and Life}

Of all the sciences, biology most earnestly lays claim to questions concerning life and movement. All the same, it is constituted by many static, analytic, and mathematical forms of knowledge. Morphological imagery gives way to taxonomical tables and evolutionary diagrams. Statistical linkages or molecular structures are the quantitative foundation to explanations of the visible behavior of living organisms. One could say that such analysis animates biological science: the merely observable regularities of life seem lifeless until the breath of formal, intelligible, analytic organization animates them as theory. Nonetheless, the observation of 
life is the necessary route to its analysis. The questions of biology-of development, growth, change, death-are, in the first place, set by the perception of movement over time. In the science of that inexact substance "life," the vagaries of belief and the systems of proof are twisted into a helix of the perceptible and the intelligible.

The Swiss biologist Julius Ries wrote in 1909 with some exasperation about the experience of observing fertilization of the sea urchin egg and the ensuing cell division.

On the one hand, a good many things in a living object happen too quickly, whereas on the other hand the advancing segmentation demands hours of the observer's attention. In this way, impressions become blurred and one gets tired. But if one attempts to capture individual pictures through sketching, one gets at the end only a composition of memory-images. The segmentation happens so fast that even the fastest sketch-artist cannot keep up with it. ${ }^{7}$

Given the difficulties of observation and the shortage of such specimens at any distance from the sea, Ries lamented that even though the cell theory is one of the foundations of biological and medical thought, the ability to witness the truth of omnis cellula e cellula was so limited that it remained "for the student something true that he must believe, without being able to convince himself of it."8

Ries initially attempted to capture what he felt to be the wonderful and overwhelming sight of sea urchin development by fixing as many stages as possible through classic histological methods. That is, he attempted to fix a different individual sea urchin egg/embryo to represent each moment of the developmental process between fertilization and morula stage. However, this did not "capture" the phenomenon adequately: "But there is still an enormous difference between the best fixed preparation and the living one. Aside from the many artifacts that are stuck to the dead fixed preparation, it also differs from the living in its motionlessness." 9 The pursuit of a biological preparation that narrowed the gap between the dead and the living-by which the student might "convince himself" of the truth that all cells come from other cells-led Ries to experiment with the new medium of film, turning away from histology and sketching. Despite continuing to call his work "chronophotography," Ries wrote that "my interest is not concentrated solely on separated images, but on the possibility of reconstructing the complete phenomenon of fertilization through projection."10 It was through projection that a preparation could retain motion and thus greater proximity to life. The machine, the film projector, was the necessary intermediary between a 


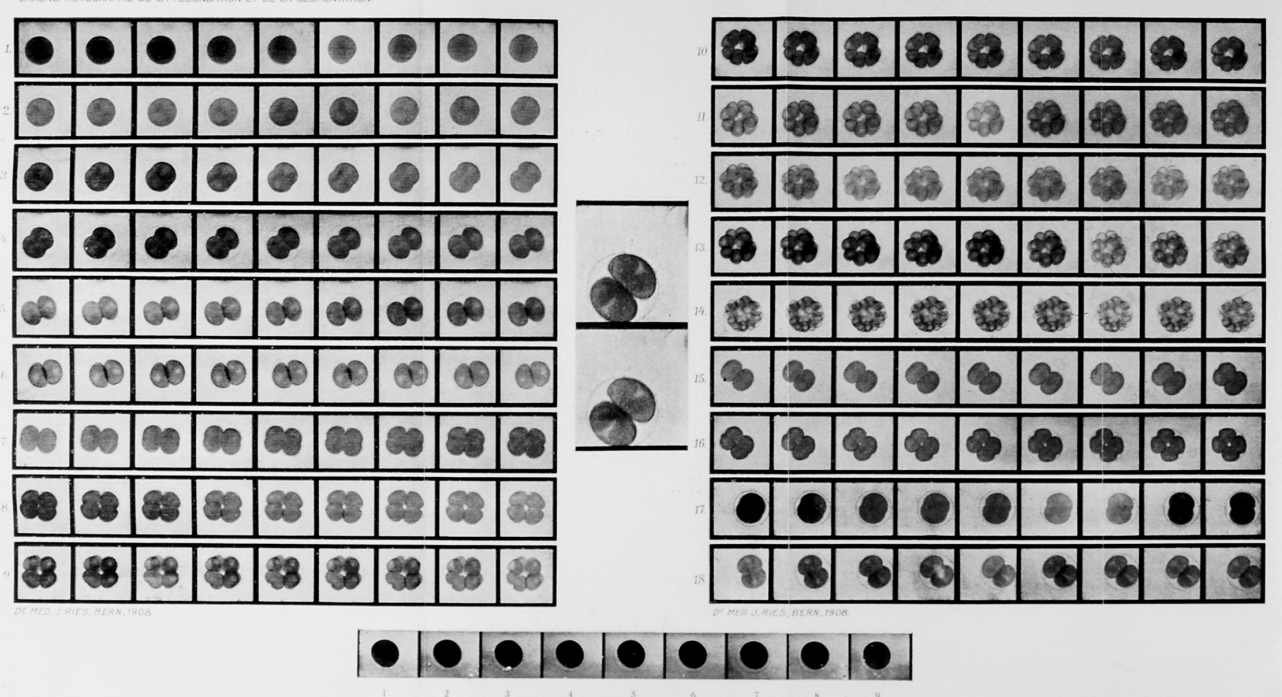

series of separated images and the reconstruction of the "complete phenomenon"-complete, that is, with motion.

Ries worked with a vertical standing microscope connected to a Lumière cinematograph. The sea urchin egg was kept in a chamber of sea water to ensure its continued life under as normal as possible conditions. A prism affixed to the ocular redirected the microscopic image of the egg horizontally into the bellows between microscope and film camera. The image was then reflected off a mirror, which was turned so that the observer could see the image from the microscope or direct it onto the film. A clockwork apparatus attached to the camera took one image every seven seconds, but to save on the film, which was available in only limited lengths, Ries set it going only during active phases of division and not during the spaces such as the hour or so that elapsed between the first division into two cells and the second division into four.

Rather than a dissection of movement, the projection of the film at sixteen frames per second was a compression of the time of development into two minutes. Furthermore, it was not a simple, homogenous compression of time; some parts of the sequence were selectively foreshortened. The given narrative of sea urchin development, already watched innumerable times by scientists looking through microscopes, in which certain stages were known to take particular lengths of time, was adopted as the original script of "subjective observation" by Ries, who then made the decision of how many images at what interval to take during each stage.

I had always to economize and not photograph until one could see a new phase of movement. ... The penetration of the sperm and the formation of a fertilization membrane lasts some minutes, then an hour passes before the formation of the primary furrow. The division takes place again very quickly, then an hour elapses before the second segmentation, etc.; the smaller the cells become, the more the pauses shorten. Having observed, through subjective examination, the periodicity of the divisions, I could set into motion or stop the clockwork during the photography at the right time. ${ }^{11}$

Despite technical problems of lighting and film length, which caused Ries to describe his production with some dissatisfaction, the effect of viewing the final 
film was "nonetheless surprising":

Even in the demonstration of my only twenty-meter-long film, which took at most two minutes to unfold, the effect was surprising; visible in the same egg is the formation of the fertilization membrane and the advancing segmentation up to the morula. One really believes one has a living, developing egg before one. ${ }^{12}$

While it may seem odd to remark that the surprise of this viewing arises in part from the knowledge that it is the same egg before the viewer at all times, it is important to remember that this form of representation-and its particular temporality-stood in contrast to other contemporary forms of depicting development. Ries's earlier attempts at fixing each stage involved a series of different eggs, each at a different (and he hoped sequential) moment in development. The very idea of development itself was not inevitable; it had been laboriously "produced" by late-nineteenth-century embryology, exactly through these sorts of sequential representations arranged into "Normal tables," thousands of individual moments in thousands of individuals built into an ascending temporal series of static moments. ${ }^{13}$ To have the same individual specimen "fixed," as it were, every seven minutes by the photograph and then put back into a highly foreshortened moving image of the developmental course by projection was therefore a surprise, inadequate lighting or no.

Meanwhile, also in Paris, Louise Chevreton and Frederic Vlès made a nineminute film of the sea urchin from egg to larva with assistance from the film production company Gaumont. ${ }^{14}$ It seems strange: two of the first time-lapse microcinematographic films made to be projected were made in the same year in the same city using the same type of microorganism, by two sets of investigators working independently of each other without knowledge of the others' production until the two films were finished. ${ }^{15}$ We can understand this coincidence only by recognizing what these films do: they seek to visualize not something utterly unknown but something entirely familiar. Sea urchins were favored model organisms for the study of development and cell division because of their large, transparent cells and their relative accessibility and manipulability. However, the illustration, proof, and capture of cells to that point was a mass of static images: fixed and stained cells, microphotographs, diagrams of stages. That they were the "obvious" choice for animation with film only makes sense in the context of this previous cycle of codification of observation: these microcinematographers saw a theory of the living illustrated by dead images and set out to animate those images, resulting in the doubled perception of the living thing and the theory of 
the living thing on screen. ${ }^{16}$

Biology is a science of cycles, but it is also composed of its own cycles of observation and theorization. Ries, Chevreton, and Vlès were not just excited by observing the thing in itself, the particular sea urchin they had under the microscope on a fine day in 1909, or even by the astonishing regularity that made the same events happening in different individuals predictable enough to set a clock by. No, they understood themselves to be simultaneously watching a sea urchin, and watching Development, Cell Theory, Life, Movement—all of which had been codified as curves, sections, and diagrams. Theory animates observation (for Ries, cell theory; for Chevreton and Vlès, graphic physiology); a machine is built to animate observation's codification, and the resulting moving image is perceived as an animation of theory.

This is not a question of true and false representations but of a cycle endlessly propelled by the competing demands of perceptibility and intelligibility within biology, in which film makes a difference in relation to previous representations of life. Certainly Ries's students already knew about cell division from looking at static drawings and by peering through microscopes at fixed histological specimens. They also knew from diagrams the putative order of developmental stages. They had perhaps even seen photographs of these stages. However, what the films did was to animate the still images-to produce the illusion of movement in the enormous projection on a screen and demonstrate, unequivocally, what they could not otherwise see: life. That is to say: we have no trouble, analytically speaking, in understanding either the mechanism of cell division or the illusion of the film apparatus. But in order to believe, in order to convince ourselves of the truth of life, both the image and the cell must be animated. This is not a leap of faith but precisely that "enormous difference," that unquantifiable quality by which a still image "differs from the living in its motionlessness."

This is not simply a leap of the imagination. Rather, it is precisely the technical difference between chronophotography and cinematography. Chevreton and Vlès commented that they could not process the 7,000 to 9,000 stills just by looking at the static film strip; the film had to be run through a projector for its content to be graspable by the viewer. There was no other access to the phenomenon. It is movement itself, the movement-image-of film cells and organic cells-that makes life visible. ${ }^{17}$ The return to the perception of movement is not a circle right back to the starting point but is itself a new cycle of observation, revealing previously "unperceived details" of movement-in this particular case indicating a kinetics of cell division that would now have to be taken into account in theories of development. ${ }^{18}$ The cycle back through observation and belief is required 
either for new generations of biologists or the generation of new theories.

Thus the movement of biology in relation to its moving subjects. The movement of biological thought is also visible to biology's practitioners. Jean Comandon, a biologist and filmmaker situated between the world of scientific research and popular film by working within the Pathé Frères film production company, made much of the epochal differences between a biology that experimented on living subjects and a former one using dead subjects. He divided microbiology into three periods: bacteriology, histology, and physiology. During the era of bacteriology, "one contented oneself then with putting on a glass slide a drop of liquid, in which one examined a minced fragment of tissue to which microorganisms were introduced."19 Despite the fact that the microorganisms were living, the preparations were poor and the visibility was bad due to the feeble contrast between protoplasm and the ambient medium. Thus the idea of coagulating the protoplasm by heat or fixatives introduced the era of histology. "That was the second period, the anatomical period," during which one studied beings killed by fixation and sectioning. "We live now in the third period that we can call the physiological period. The laborious researches of our forebears have put our classifications in order; they have made known to us the structure of cells." However, with the power of microcinematography, "now, one observes them anew in the living state, one can follow their modifications, their evolution; one experiments on the action of diverse chemical reagents or physical events that change their milieu." 20

In 1914, while showing a time-lapse microcinematographic film of cell division to the members of the Institut Général Psychologique, Comandon drew the audience's attention to an entity whose very name derived from histology: chromatin, so named for its ability to take up histological dyes. Chromatin, which had come into existence for biologists as a thing killed by its visualization, was neither colored nor dead on film. It was animated, in all its brilliance, by cinematography, making the audience see not just the thing in motion, but see anew the thing and its name and the conditions of its visibility.

You see a kind of brilliant reticulum, formed of a substance, chromatin, so named because it selectively takes up certain colors that are used in histology. Caryocinesis has in effect up to now scarcely been studied other than with histological procedures, on dead cells, fixed and then colored, submitted, in sum, to so many manipulations that certain authors have even denied the real existence of these figures, so curious and so complex, that you will see following one upon the other. ${ }^{21}$ 

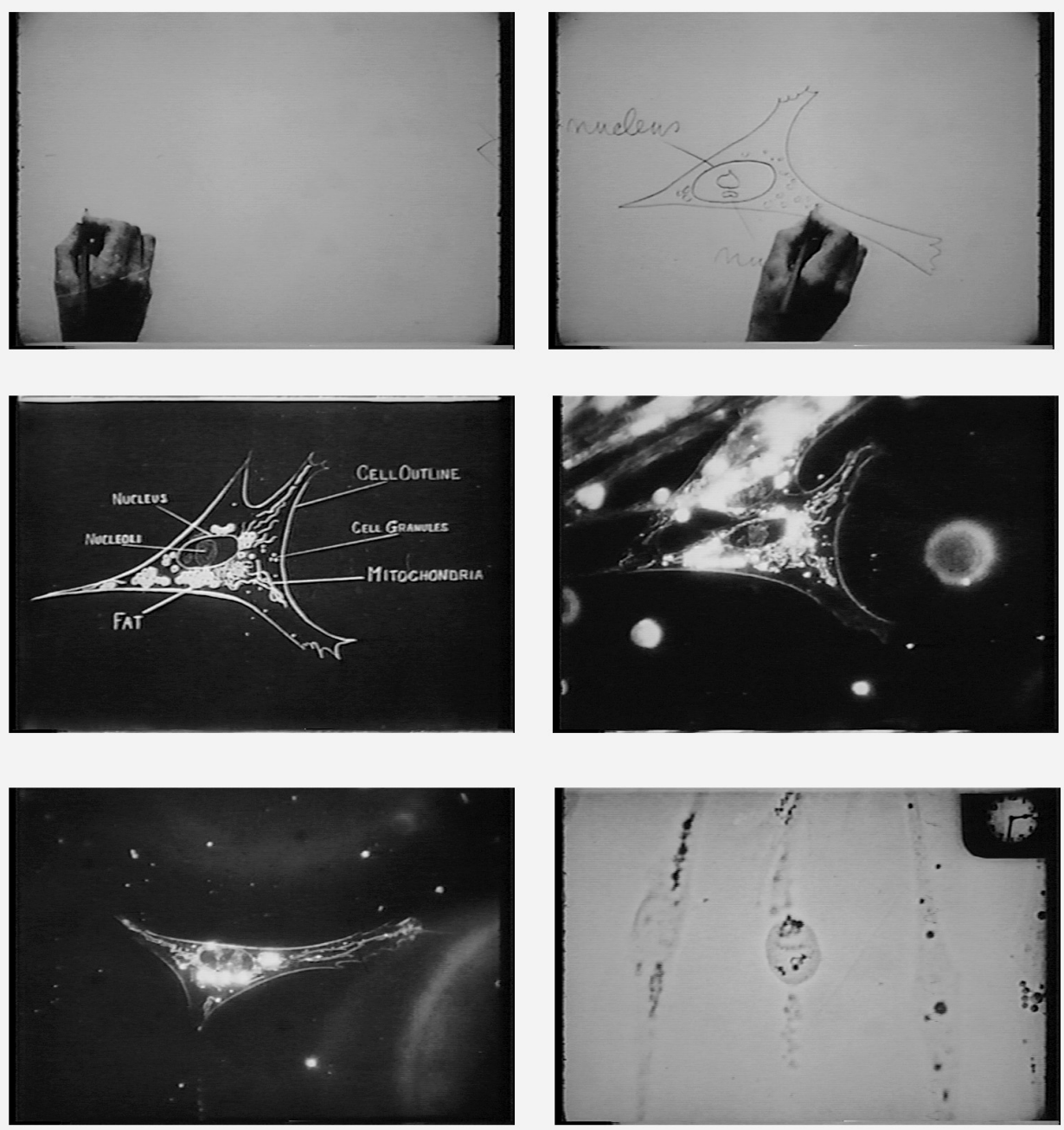

Again there is an admixture of technique and belief. The technique of histology had been designed to visualize life. This led to the attempt to study life in dead cells, and the manipulations of fixing and staining cells led some to disbelieve that chromosomes formed these mitotic figures altogether. While these dead figures had "put our classifications in order" and elaborated the structure of the cell, it was then necessary to return to the observation of life. For Comandon, microcinematography, by contrast to the doubt and artifactuality of histology, produced a "gripping truth."

While one method's proponents may understandably disparage another, the movement of visualization techniques should not be understood as a succession of techniques supplanted in series, because it is exactly the necessity of the backand-forth between perception and intelligibility that constitutes the comprehension of life. This back-and-forth begins to appear, with the advent of better splicing techniques, within single microcinematographic films. For example, in The Cultivation of Living Tissue (1927) by Ronald Canti, the film cuts between a hand drawing a diagram of the cell on the board, a static cartoon with its organelles labeled, and time-lapse sequences of living cells, writhing and crawling across the field of view as a chronometer twirls in the upper-right-hand corner of the frame. Another striking aspect of Canti's films is their demonstration that the 
biological concept of death can also be animated with film. The teeming field of dividing cells is subjected to intense radiation, and as the moments swirl by, counted by the chronometer, all movement ceases and the viewer is left shocked by the stillness within the moving image.

\section{Part 2: Formalization and Death}

As it became clearer over the twentieth century that cell death was not a simple cessation of life but a complex physiological process of organized dying common to all cells at all stages of life in all organisms (much like cell division), the role of film in animating death became more important. ${ }^{22}$ In 1976 scientists trying to elaborate the process of cell death exploited the properties of film to aid in the perception of the sequence of dying, the "death agony" of the cell:

Films were examined in a photo optical data analyzer . . . which allowed forward and reverse examination at different speeds. ... In general, the most suitable technique was found to be a retrospective examination, starting with a dead cell towards the end of a film and following it backwards. This enabled the cell to be observed before and through the phases of death. ${ }^{23}$

The dead cell could be, like a cartoon character flattened by a truck, animated back to life, backward, to determine the exact course of dying.

In the late 1980s genes controlling the suppression or triggering of cell death during nematode development were mapped. By the 1990s the study of the genetic and molecular action of this process of death had become one of the hottest fields of biological research and the subject of the 2003 Nobel Prize for Medicine. Biologist William R. Clark gives a dramatized account of the search for the mechanism by which cytotoxic T lymphocytes (CTLs) kill cells that are damaged or foreign. He recounts that scientists were looking for "a smoking gun or bloody knife, for a rope or traces of poison," but no matter how much they studied the process "from start to end, no truly believable weapon could be found."

And then one day ... someone decided to take a closer look at the target cell in its death throes, just after it had received the "kiss of death" from a killer T cell. . . . Enlarged images were projected on a screen, run forward and backward; sped up and slowed down. As expected, the CTLs approached the targets, bumping and probing and then locking on tightly for several minutes. But as the target cell was released from the CTLs embrace, it began to do what everyone suddenly realized was the classic cellular dance of 
death. . . . This sent scientists racing back to the lab to monitor the state of the target cell's DNA during the killing reaction. ${ }^{24}$

Only through seeing the "classic cellular dance of death"-by watching the behavior of two cells in time "before and through the phases of death" on filmcould these scientists discover that the cytotoxic T cell did not kill the target cell; rather it signaled it to kill itself. This observable phenomenon was formalized as "apoptosis" or "programmed cell death" and is now characterized by specific quantifiable molecular changes, such as a cell's enzymes cutting its own DNA into pieces. However, Clark's narration implies that somehow cinematography is not a laboratory procedure like DNA analysis; the cinema-going scientist has to return to the lab after the film, perhaps to track down what is really happening at the next level of subvisibility, and so on from perceptibility to intelligibility.

Why is it only in the last decade of the twentieth century that cell death is recognized by the biological research community as a fundamental property of all living beings at all stages of the life cycle? The answer, in short, is that cell death had been "seen"- - observed, studied, commented upon, plenty of times before, but as we have said, observable regularity is a necessary but inadequate prolegomenon to formalization. Film provided the plot-scientists raced back to the lab; genetic and molecular analysis ensued; and a biological theory of cell death as integral to ongoing life began to take on a certain life of its own, "invading not only the minds of many biologists but also many fields of biology." 25

Henri Bergson commented, in observing science, that one of the difficulties posed by the symbols by which our intellect represents biological objects to us is the problem - at once technical and philosophical—of the time of the object and the time of its representation. "We are at ease only in the discontinuous, in the immobile, in the dead. The intellect is characterized by a natural inability to comprehend life." 26 Thus the interplay of the perceptible and the intelligible in microcinematography speaks to the larger scene of biology: living beings change continuously over time, and, as a result, biology's experimental techniques include a repertoire of means with which to halt, suspend, freeze, denature, or otherwise hold its innately dynamic subjects still, in forms amenable to visualization, representation, analysis, exhibition, exchange, or storage. From collectors' cabinets to freeze-drying, from histology to electron microscopy, from dissection to DNA sequencing, biology is armed with methods to stop a being in its tracks, to stop it at a particular point in its life (which often means to kill it) in order to study it. These techniques exist in a tense reciprocity with those that observe the living organism over time; for example, vivisection or vital staining. 
Media that represent the living organism over time, such as time-lapse microcinematography, not only demonstrate the life of the organism in question, they also animate it in relation to other, often dominant, modes of static representation.

However, in the historical record, it is generally the analysis that remains and the mode of initial observation that falls away. Microcinematography is not generally recognized as significant to the making of biological science, despite its constant role of reminding biologists that their subjects are alive. Even in 1962, C.H. Waddington wrote that "many biologists still seem to experience something of a shock when they see such films and realize that cells have to be considered as highly active bodies in which movement of the internal constituents is continuous and uninterrupted." 27 Like Ries, Waddington felt film was a necessary corrective to the de-animating effects of microscopic technique. While he readily admitted that "Time-lapse films, of course, exaggerate the speed with which these movements are carried out," he also argued that "the point they bring home so forcefully, that cytoplasm is always in a state of physical activity, is a perfectly valid one." In fact, exaggeration was "useful to counterbalance our tendency to envisage cells in terms of the static pictures presented by ordinary microscope preparations." 28

Such images of cells were also critiqued as not only insufficient analytical tools, but distracting ones. The biologist Peter Medawar described people doing time-lapse cinematography in the 1920s and 1930s as having been "delighted, distracted, and beguiled by the sheer beauty of the cultivated cells" and as a result having missed the opportunity to use cell culture to-as he put it-“solve biological problems." ${ }^{29}$ The criticism voiced by Medawar is only one specimen of the constant call to formalization: what good will "just looking" at life do, when there are immune reactions to figure out, forces to quantify, DNA to sequence, regularities to ferret out?

Here, at yet another turning from observation to formalization, we begin to address the question of what the "analog" image of the dividing sea urchin egg in 1909 has to do with the "digital" image of the brain in 1999. What binds these two confrontations of static media with time, movement, and the organic? One way to approach this question is to shift the focus from the images themselves to their construction. Much as an understanding of the filmic apparatus can clarify the illusion of movement, so too can a short genealogical excursion through mathematical formalization of biology give us an understanding of the relation between the initial observations of the movement constituting plant growth, the intermediary formal grammar for describing branching structures, and the final digitally cultivated image of the living, thinking brain. 
Aristid Lindenmayer, botanist and developer of L-systems (L for Lindenmayer), the formal grammar used to make the Fight Club opening sequence, was from the start guided by a desire to axiomatize biological knowledge; that is, to see biological facts as axioms or statements from which theorems might be derived through deductive logic. Such an endeavor of formalization would, in the eyes of many, make biology a true science. Lindenmayer turned first to J.H. Woodger for help in understanding how mathematical logic (in particular, the logical calculus of Russell and Whitehead) might be imported into biology. ${ }^{30}$ The system Woodger invented was based on the predicate calculus of Russell and Whitehead's Principia Mathematica and consisted of a set of logical operators. These included:

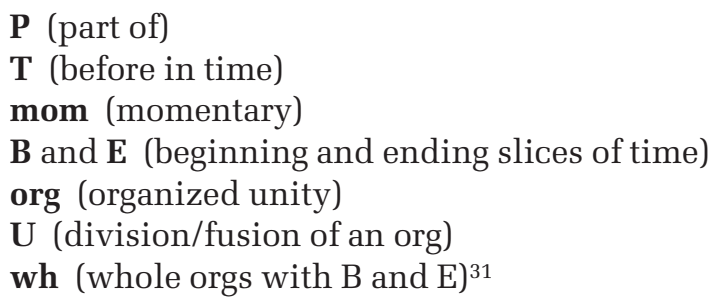

These logical operators were intended to stand in for components of biological knowledge, thereby using empirical biological work as the basis of axioms from which biological theorems could then be derived. ${ }^{32}$

Woodger's attempts were pencil-and-paper exercises in writing logical statements and using the calculus to verify them. To "do" biology in this sense was to "observe" these forms - to engage the mathematical imagination, to imagine a set of statements about biological organisms as if they were axioms of the Principia, and to calculate using its theorems. Outcomes of calculations on properly stated axioms would be, in short, answers to biological questions. Woodger was steadfast in his desire for an axiomatic and logically consistent system (though modest in his own claims to have achieved it):

An intense interest in, and intimate first-hand acquaintance with, organisms, indispensable as it is, will not alone lead biology to the goal of an exact science. If "form" is the essence of the whole business, it is necessary that theoretical biologists should concentrate on the discernment of the form of biological fact and cultivate the study of the abstractly embodied forms offered by pure mathematics and logistic. ${ }^{33}$

Where Ries or Comandon looked at histological codification of cell division 
and thought something essentially lacking, an insufficient scientific representation which crucially differed from the living object in its motionlessness, Woodger saw representational insufficiency in the other direction: inadequate mathematical symbolization. Observation alone-mere "acquaintance with organisms"differed crucially from the logical in its motion, its continuity. While the desire to visualize life remains constant, this is the complement to microcinematography, the attempt to animate mere observation with lively theory through new forms of codification.

Woodger's sentiment echoes across the twentieth century and is perhaps most salient in the heart of modern theoretical biology and computer science. It is perhaps the first taste of an attitude toward logic (like that of theoreticians of formal languages and artificial life) that deliberately experiences it as something almost alive-something with a form of its own that must be observed, illustrated, and cultivated like life itself. That it was manifestly associated with the study of things fully and obviously alive, rather than with the dead symbols of mathematics or the inorganic offerings of chemistry, simply blurred the lines further.

Lindenmayer made a valiant attempt to extend Woodger's original work in a paper titled "Life cycles as hierarchical relations." ${ }^{4}$ Following Woodger's lead, and using the idioms of the Principia Mathematica, Lindenmayer delivered a similar array of dense symbolic logical statements covering modern biological knowledge-but they differed in a crucial way. His 1964 paper used only three simple primitives: mitosis, meiosis, and fusion. It was cellularity (the organism as a sum of discrete but repetitive entities) that characterized Lindenmayer's approach. And to see cellularity clearly, it was necessary to see mathematical logic clearly. Lindenmayer explains: "Theories are considered in modern logic as languages.” For Lindenmayer the theories rendered from biological experimentation (e.g., the stages of mitosis or meiosis) are not just statements; they are languages. They are not just sets of equations or strings of hieroglyphics but complete systems with specific, enumerated grammars capable of generating new forms.

Lindenmayer's claim that theories can be seen as languages and that languages have a logical structure might seem obvious, but we suggest it should in fact be read as a kind of discovery: a discovery that by representing theories as languages, they can be observed. ${ }^{35}$ However, the implication of this discovery did not become clear until Lindenmayer moved away from the mathematics of the logical calculus and toward the theory of computing machines. In 1964 such observation of language was difficult for two reasons: one, it involved differential equations 
whose solution would have required far more computing power than was then available; and two, because it was difficult to see the logical description as anything but the organisms it purported to represent. The form of the description was rigid-it was subordinate to, and had the same structure of relations as, the description of the organism.

But conceived of as "languages," theories become like the biology they purport to describe: natural, evolving forms with dynamics and features all their own. This doubling of life by the languages that describe life will become especially fecund when these languages are not imagined (with the aid of pen and paper) but programmed into machines and, like the life they describe, are literally observed over time-languages that come alive because they are given a new home in discrete machines that operate in continuous time. Because they are themselves logical, computing machines help figure out what a theory looks like. On screens, in printouts, they show the scientist what happens to a theory over time. ${ }^{36}$

\section{Part 3: Do Words Live?}

She said the hardest thing to teach her three-year-old kid was what was alive and what wasn't. The phone rings and she holds it out to her kid and says, “It’s Grandma. Talk to Grandma.” But she’s holding a piece of plastic. And the kid says: "Hey, wait a minute. Is the phone alive? Is the TV alive? What about that radio? What is alive in this room and what isn't?" Unfortunately, she doesn't know how to ask these questions. ${ }^{37}$

Patchcords in one hand and potentiometer knob in another, the modeler observes through the screen of an oscilloscope selected aspects of the model's behavior and adjusts the model's parameters ... until its behavior satisfies his criteria. To anyone who has had the pleasure of close interaction with a good fast responsive analog simulation, a mathematical model consisting of mere pencil marks on paper is likely to seem a static, lifeless thing. ${ }^{38}$

In 1968 Lindenmayer proposed a novel way of modeling a biological organism: he borrowed a formalism from the nascent theory of computer science that was capable of powerfully representing the cellularity of an organism. ${ }^{39}$ For an arcane theoretical paper that combined relatively new and difficult concepts from the mathematics of computing machines with the study of the growth and development of filamentous organisms, its impact was profound. Not only was this a provocative model of developmental growth in certain kinds of organisms, it 


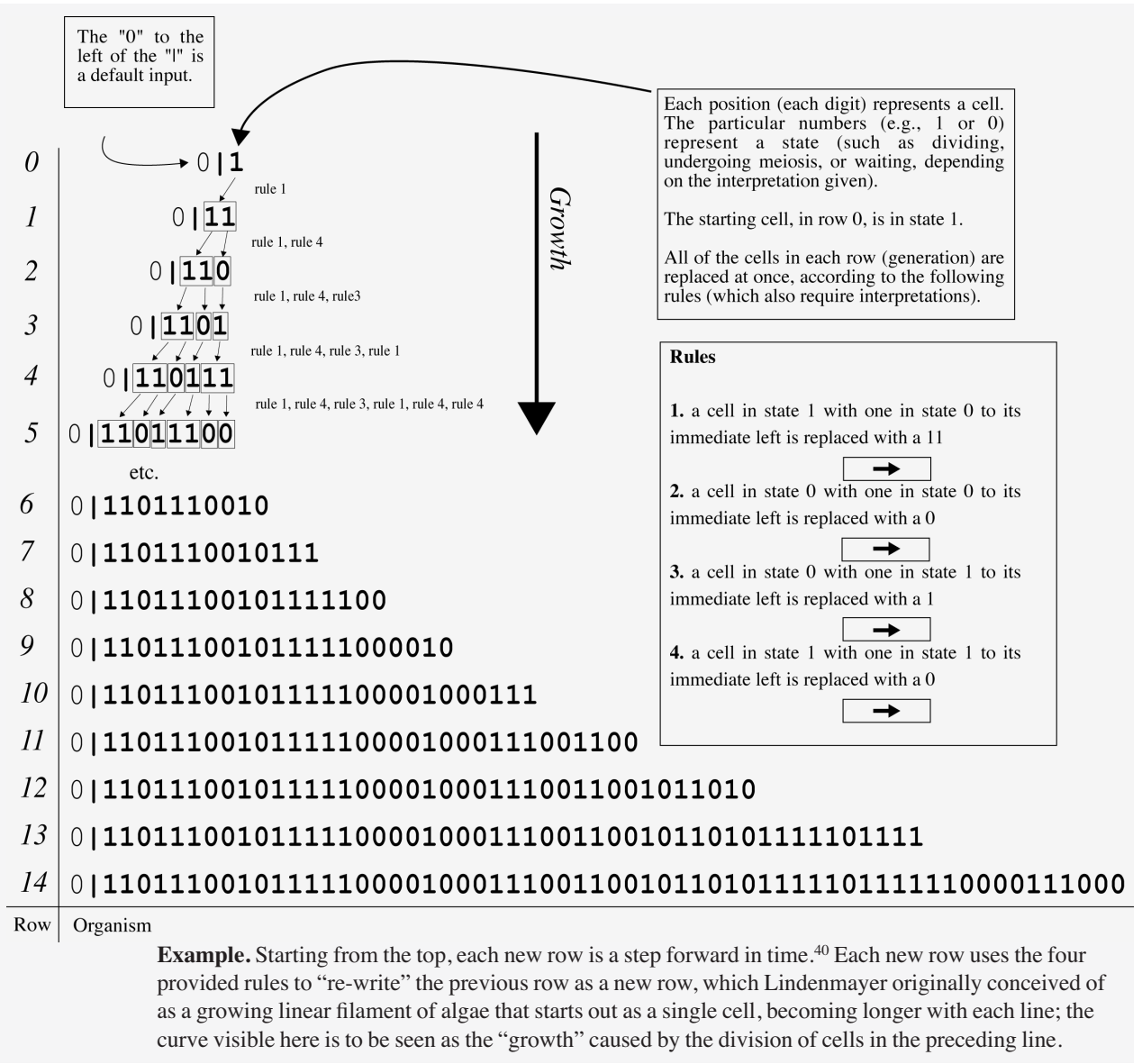

spawned a subfield of the mathematics of formal languages that, by 1996, had produced an estimated 5,000 articles and merited extensive coverage in the threevolume Handbook of Formal Languages. ${ }^{41}$ Indeed, the productivity of the mathematical formalism would eventually overwhelm its usefulness as a biological theory.

An L-system is a "formal language.” Though L-systems are often referred to by the terms alphabet, grammar, or language, they are mathematically formalized concepts. In Lindenmayer's 1968 description (see example and figure above), the cells of an organism are represented formally by their positions on a line, and each position contains a symbol, which shows the cell's state, in this example a 0 or a 1 (this two-symbol "alphabet" is given at the outset). A set of rules-a grammar-governs how these numbers change state from line to line. The grammar can be programmed as a set of operations to be carried out by a computer (as Lindenmayer's first models were on an IBM 1620 and 7040, in FORTRAN II). The rules themselves can be given any number of biological interpretations (e.g., in the example above they may refer to some kind of chemical or physical instructions). These early attempts had no pictorial (i.e., on-screen) component, but the movement of the program was produced as printouts. Just as instruments of graphic physiology traced the movement of organisms over time, these printouts traced the movement of the model of the organism over time. For instance, the example from Lindenmayer's article might help the reader see what an L-system representation of a simple one-dimensional cellular organism looks like as it develops. 
In this simplified case, it is possible to work out each successive stage of "development" by following the rules and replacing each row with the next. This example could be produced by hand, on paper, but as the authors of one of the earliest computer programs point out: "To find out the way in which a cellular iterative array will develop is a very tedious job without the help of a computer. In fact, in all but the simplest cases, time would put a stop to a pencil and paper attempt to follow the pattern of development." 42

From this point, the time-lapse of computation is essential to the observation of L-systems development. Even simple adjustments (adding more rules, making a rule nondeterministic) require enlisting the aid of a computer and printer. Just as the small dark gap between images on the film strip held in it not only all the labor of prolonged observation but also the physiological limit of the human eye to perceive motion, so the ability of the machine to process and condense the "lapse" between moments/lines was an essential part of the perception of development or movement in computation. And as with cinematography, the actual implementation, the software, is perceived as technical and secondary to the formal presentation and does not appear in many publications. Nonetheless, it is only via the process of programming a machine to calculate an L-system that one can claim to see a "theory" over time. Like Ries, who had to go through the machine of the cinematographic projector to access "the complete phenomenon" of development in motion, the computer is necessary to the visualization of development over time. Imagining development, such as Woodger had attempted, is suddenly much less interesting than the practice of waiting for and watching a language develop in a computer over time.

The 1968 papers were a breakthrough for Lindenmayer, who had struggled to find a path from continuous to discrete representations of biology. In a 1983 interview he noted his long-standing interest in "structures which are partly continuous and partly discrete." The structures could be colloidal suspensions, or they could be cellular organisms. ${ }^{43}$ Again we see the powerful confrontation with time, movement, and the organic which has always troubled the biological sciences. The concern over the description of biological organisms as continuous or discrete brought Lindenmayer to the study of "sequential" or "finite state" machines-the subject of the then young field of computer science. In particular, it gave him a way to model organisms as collections of cells-just as the "finite state" machine was always pictured as a set of connected, discrete boxes or circles.

How did Lindenmayer make this transition between 1964 and 1968 ? $^{44}$ The apocryphal story goes like this: Aristid Lindenmayer was walking through the halls of his university and passed a lecture room in which a professor lectured on 

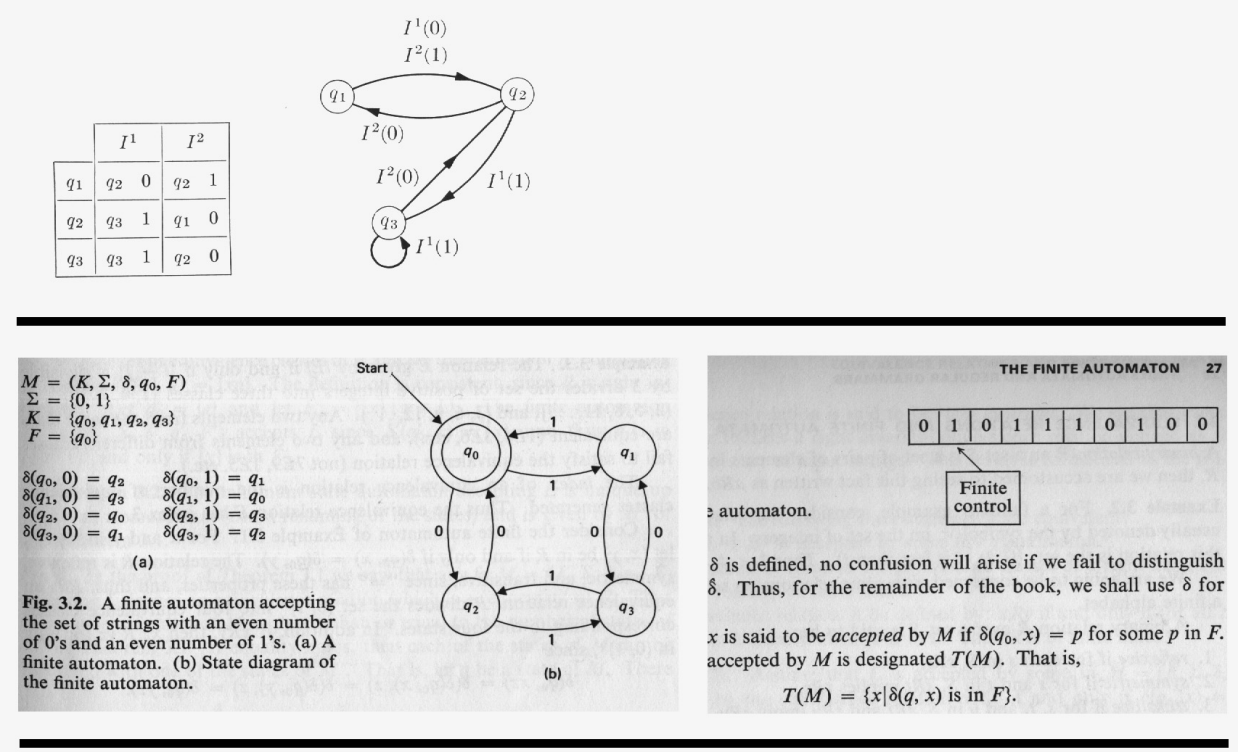

through a head, which is situated, at each moment, on some square of the tape (Fig. 6.0-1). The head has three functions, all of which are exercised in each operation cycle of the finite-state machine. These functions are: reading the square of the tape being "scanned," writing on the scanned square, and moving the machine to an adjacent square (which becomes the scanned square in the next operation cycle).
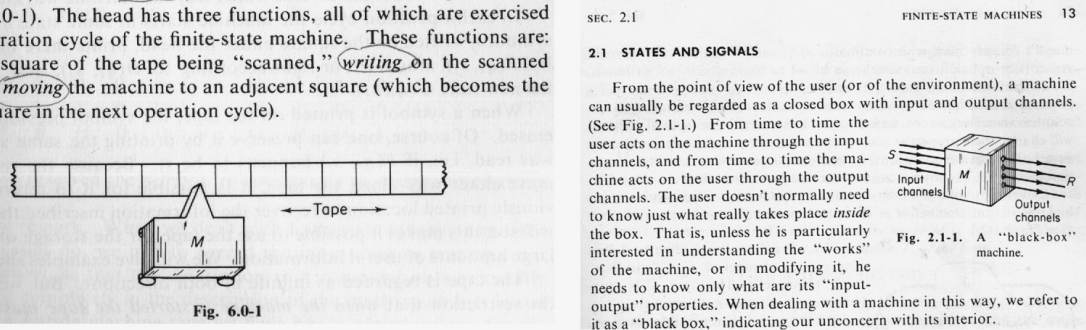

formal languages. The instructor talked about the relationship between strings and words, languages and grammars, referring repeatedly to a language $L$ formed from grammar G, or L(G). The young Lindenmayer heard not symbols but, of course, a word: algae. $\mathrm{L}(\mathrm{G})$. Algae. It is perhaps not an accident, therefore, that the first organism modeled by L-systems was also algae, Callithamnion roseum-or perhaps it is only because Lindenmayer knew algae that he could see clearly the possible uses of L(G). Chicken/egg.

Lindenmayer's deliberately illogical connection-seeing $L(G)$ as algae-was perhaps not so odd at the time. L(G) was in the water. John von Neumann's work on cellular automata was written as early as 1948, but republished in 1966; 45 the work of McCulloch and Pitts ${ }^{46}$ had become the subject of Kleene's famous paper on "nerve nets" as regular languages, which led to a host of work on "finite automatons", ${ }^{47}$ Stanislaw Ulam had published a paper on "the growth of figures," 48 and a variety of other attempts to model biological organisms were already underway. Lindenmayer used Seymour Ginsburg's early work Mathematical Machine Theory, ${ }^{49}$ which itself suggests that sequential machines are everywhere ("safes, vending machines, data processors"). This provided Lindenmayer with a way to imagine a line of cells (a filament) as a number of sequential machines all processing inputs and changing states-perhaps depending on the states of the cells around them. As obvious as it might seem in hindsight, the connection is necessarily an imaginative one based in an understanding of real 
biological phenomena filtered through real mathematical logic and confronting problems of continuous and discrete representation. Regardless of its subsequent success, there remains, ironically, no logical reason to imagine that algae are $\mathrm{L}(\mathrm{G})$. At best it is a poetic match-up between the ubiquitous cells of biology and the equally ubiquitous lines and circles of early computer science. As a result, the 1968 papers are relentlessly mimetic-symbols are referred to as "cells" almost from the beginning. Each stage of the theory is accompanied by a statement of the form "much like that observed in plant shoots and roots" and the use of the words basal, apical, and helical to refer to the sequences of zeroes and ones.

Interest in L-systems took off nearly immediately. Throughout the seventies and eighties a variety of attempts were made to use L-systems in experimental or theoretical biological contexts, many of which were coauthored by Lindenmayer or his students. Because one of the initial simplifications of L-systems was the assumption of a static configuration of cells (cells in L-systems have constant neighbors, and they don't move about), there could be only an avowedly herbaceous interpretation; hence the vocabulary of apices and helical structures, the imagery of roots, trees, branching, and rhizomes. Animal cells move and jostle, as was evident to the microcinematographers of the twentieth century, and are therefore unsuitable to being represented as arrays of fixed blocks with constant neighbors. Even animation has its limits. ${ }^{50}$

Lindenmayer's struggle with the problems of the continuous and the discrete in the representation of organisms and of theories is nicely illustrated by one of his assumptions: "Cell death can be represented by introducing an 'empty state' (e), which is needed for theoretical reasons anyway, and having some combinations of states and inputs, e.g., $p$ and $q$ such that $\partial(p, q)=e . "{ }^{51}$ Because the model is intended to simulate the development of a cellular organism, it seems only natural that some notion of death be present. Whereas a model of, for instance, crystal formation might not require a notion of death, mathematical formalism necessitates the existence of an empty set, as Lindenmayer says, "for theoretical reasons anyway." It is unclear which comes first, death or the theoretical, but the necessity of the empty state is not driven by a biological observation, but only by the insistent problem of continuity in both cells and machines. One way to grasp the problem is to ask the question, When one cell divides into two, what happens to the first one? Does it "die"? Does it "disappear"? Or does it become two cells? Does it "give birth" to one cell? To two? Finite state machines have no way to represent the notion of a cell becoming continuously smaller or larger except through a discrete change of state. How one decides the answers to these questions determines what kind of L-system one uses; namely, a "propagating" or "non- 
propagating” L-system. The assumption that an organism has states leads to the creation of different formal symbolisms than from those focused on capturing a continuously changing organism. And while it is true that an infinitely fine series of different states may well capture something like continuity, the very real temporal limits of the discrete computer intervene.

In 1968 theoretical biologist Brian Goodwin commented that the two main types of computer currently available, analog and digital, reflect with remarkable fidelity two quite different approaches to the analysis of biological systems. Analog approaches, he said, emphasize the dynamic, continuous aspects of processes such as physiological activity, while the digital approach emphasizes the quasi-static, discontinuous, logical aspects of phenomena such as speciation in genetics. Fields like embryonic development are therefore particularly theoretically intractable because they incorporate both aspects. He proposed a kind of hybrid machine of the two but wrote that "which partner is regarded as ultimately ruling the whole machine depends upon the point of view and whether your sympathies lie with Bergson or with Russell." 52

Lindenmayer was troubled by precisely this tension. It is ironic, therefore that the biological usefulness of L-systems was eventually swamped by the interest from mathematics and computer science. The enthusiasm is attributed to the special characteristics of L-systems as compared to other formal languages (e.g., cellular automata, regular languages, or pushdown automata): the fundamentally parallel system of rewriting. In the example given above, for example, all of the cells in a given row are to be replaced at once; if the rules were applied sequentially rather than in parallel, then the state of the cell to the left could change before the rule was applied to the next cell, leading to different outcomes. Such differences have both mathematical implications and interpretive (biological) ones. The choice made by Lindenmayer to have all of the cells change state at once betrays an almost metaphysical assumption about the homogenous nature of time in a biological organism. Time, in the L-system, progresses as a series of discrete steps, and cells are assumed to go through time together, as it were, neither faster nor slower than one another. Though this interpretation is meant to capture the centrality of time to the living organism, there is but one timeimage at work in the language of L-systems: that of the regular pulse of the computer chip.

\section{Part 4: Interpretation}

By the early 1980s L-systems were so successful that their biological justification began to seem less and less essential. Lindenmayer himself at this juncture said, 
"it is probably better to accept the fact that each mathematical theory has its own life and internal development, and it certainly is not the task of biologists to tell mathematicians what they should or should not find interesting or worth pursuing." ${ }_{53}$ The diversity of possible extensions was of significantly more interest to computer scientists and mathematicians than it was to biologists-though part of the charm and aesthetic appeal of L-systems no doubt derived from their biological origin. However, because biologists could do little with L-systems does not mean that we leave the domain of life or of the visualization and animation of life or its theories. Quite the contrary, because each mathematical theory has its own life and internal development, we are quite literally confronted with the question of whether L-systems themselves are alive.

Johann Wolfgang von Goethe chose, as an epigraph to his famous work on The Metamorphosis of Plants, a line from Epictetus: "What disturbs men's minds is not things themselves, but the interpretations placed upon them.” Henri Bergson's Creative Evolution echoes the sentiment, stating, "simplicity belongs to the object itself." Infinite complexity, on the other hand, belongs to "the views we take in turning around [the object], to the symbols by which our senses or intellect represent it to us, or more generally, to elements of a different order, with which we try to imitate it artificially, but with which it remains incommensurable, being of a different nature." ${ }^{4}$ Such questions are familiar to the discourse or discipline of "artificial life" wherein the insistence that moving images on a screen are "really alive" or "really natural" has been extensively discussed. ${ }^{55}$ While L-systems fit firmly among the tools and techniques of artificial life (including the cellular automata of John von Neumann, John Conway's game Life, and the so-called genetic algorithms), it is not the case that all theoretical computer scientists consider themselves "artificial life" researchers; in fact, probably only a very few do. Nonetheless, all of them are confronted with a question of the interpretation, in the sense that both Goethe and Bergson gave it, of what they write on paper and what they watch on their computer screens.

As mentioned above, Lindenmayer's early attempts to model biological theory with the Principia Mathematica led to a relationship of resemblance, whereby the relations of biological theory were made to resemble the relations of the logical calculus. The finite state-machine representation, on the other hand, is slightly different. The resemblance between the machine and the theory is not a correspondence of relations but only a shared assumption of cellular state and discrete temporal development. That an L-system is (or models, or represents) a biological organism is only one among many interpretations. An L-system is by itself a thing: a logical machine that is observed to unfold in time. Whether or not 

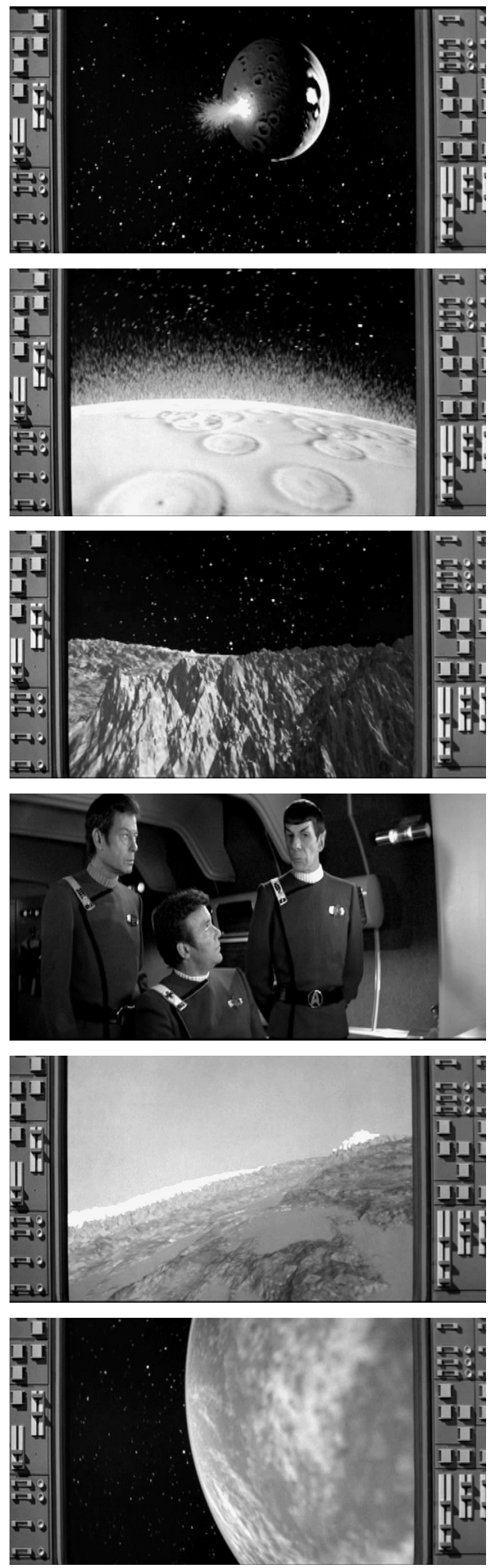
"Project Genesis," it transforms dead and lifeless planets into lush blue-green globes. In the film, Kirk, Bones, and Spock watch a simulation of this process on a computer screen. The sixty-second scene-a flyover of a barren moon that is first covered with fire, then transformed into a mountainous blue-green planet-

Project Genesis sequence,

Star Trek: The Wrath of Khan.

Dir. Nicholas Meyer, 1982.

it does this in a manner similar to that other machine, the cell, depends on the interpretations or images given to the L-system by the human manipulating it. The cells of the machine are not required to be only the cells of an organism but can also be modules of a plant (inflorescences) or regions of a cell (as in the Fight Club sequence, which models the axons and dendrites of a single cell), or any other "cellular" structure. L-systems as theories are of a different order than organisms-and yet the views we take in turning round both theories and organisms are strikingly similar.

There is also a second sense in which interpretation comes to play a role in L-systems-and here it is the technical term used by computer graphics specialists themselves: it is when the strings of symbols that may or may not be algae are given a visual representation as algae, or as plants, or as neurons. ${ }^{56}$ If the first interpretation is a textual or rhetorical claim that a given set of symbols are a certain kind of algae, the second interpretation is simply the replacement of these symbols (and the claim of being biological) by a picture of algae. The process by which this computer graphical representation of an L-system is possible requires another layer of computing power, another confrontation with the vagaries of the continuous and the discrete, and another trip through Hollywood.

Among the many filmic representations of artificial life, or of science fiction images of life in or out of control, one occupies a special historical place. In Star Trek: The Wrath of Khan (aka Star Trek II; 1982), starring Ricardo Montalban, there is a scene in which a powerful technology is demonstrated to Admiral Kirk, Captain Spock, and Captain McCoy. Dubbed 
was one of the first full-screen 3D graphics scenes in a Hollywood movie. It is perhaps ironic that this demo-within-a-demo should have been created using, in part, lively formalisms like those of L-systems. It was the science fiction dream of a complete reorganization of matter into a new reality, mirrored inside the software by the reorganization of a formal biological theory into a graphical representation of this fantasy. ${ }^{57}$

Project director Alvy Ray Smith at Industrial Light and Magic (George Lucas's special effects company) insists that this was a special chance for his team to show that computer graphics (CG) could be used to simulate a scene rather than simply appear on the computer screens of profilmic actors. ${ }^{58}$ The Star Trek II demo represented a chance to demonstrate to Hollywood just how powerful computer graphics techniques had become by 1981 .

Prior to his career in CG, Smith had been a computer scientist working on cellular automata; he later became famous for his work at Pixar, including on Toy Story. What made the Star Trek II demo historically significant in terms of computer graphics was the use of what Smith called "database amplification" techniques, including those drawn from formal languages, as well as the work of Benoit Mandelbrot on fractals. Loren Carpenter used a simple fractal graph-replacement grammar to model the mountains that would appear on the planet as it was transformed. By setting a small set of rules (the database to be amplified) for the replacement of simple shapes (triangles), what appeared on the screen was an excellent facsimile of mountains, generated entirely by the machine. That is, rather than painstakingly illustrating a mountain in each frame, the triangle mountains were "grown" (just like the brain of Fight Club) from frame to frame, then given an "interpretation": color, texture, and shadow to give the mountains a familiar look.

Smith explained these techniques (and the notion of "interpretation") in a paper ("Plants, Fractals and Formal Languages") presented at the 1984 SIGGRAPH conference. The paper is an explanation of how to use "graftals" (including Lsystems) to generate pleasing graphical images of plants and, importantly, plant development. Both L-systems and Mandelbrot's fractals, according to Smith, are modes of "database amplification," which is "very important for the construction of satisfyingly complex scenes in reasonably short times." 59 That is, like the painstaking observation of a dividing cell, the painstaking creation of an animated one simply takes too much time.

L-systems, as designed by Lindenmayer, do not by themselves generate visual images. They are only strings of numbers or letters. In order for an L-system to look like an organism, layers of "interpretation" must be applied to turn them into graphical images. First the symbols must be given an interpretation as graphs 


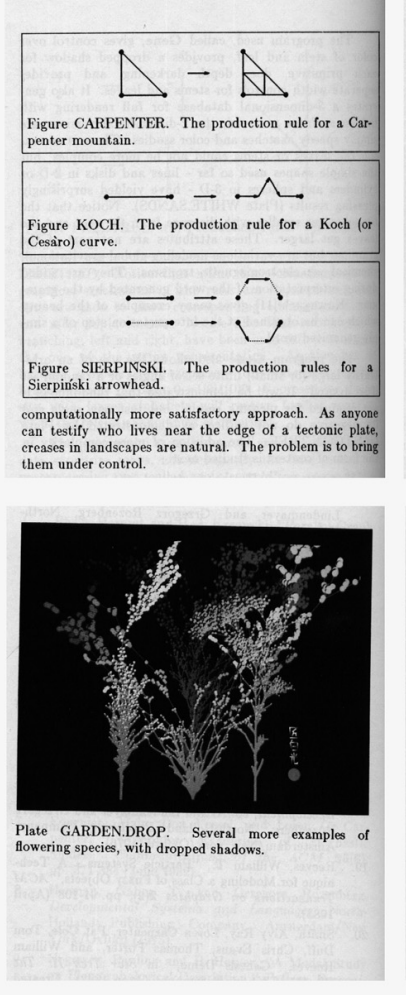

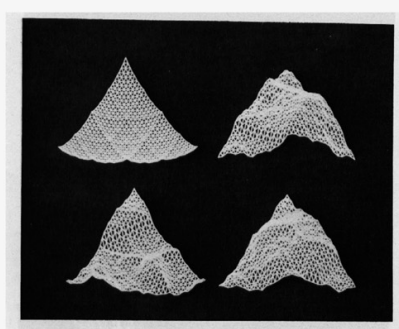

Plate FOUR.FRACTAL. The upper left mountain results from only one subdivision factor. It is unsatisfacfully chosen factors, and the lower left from five. They both work. The lower right mountain is generated using random factors. It is elear that deterministic mountains (e.g., the upper right one) suffice.

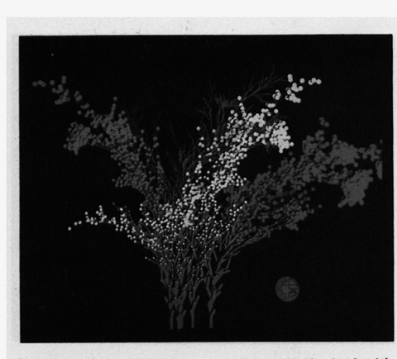

Plate VITA.PLANTS. Several variations obtained with the Gene program.
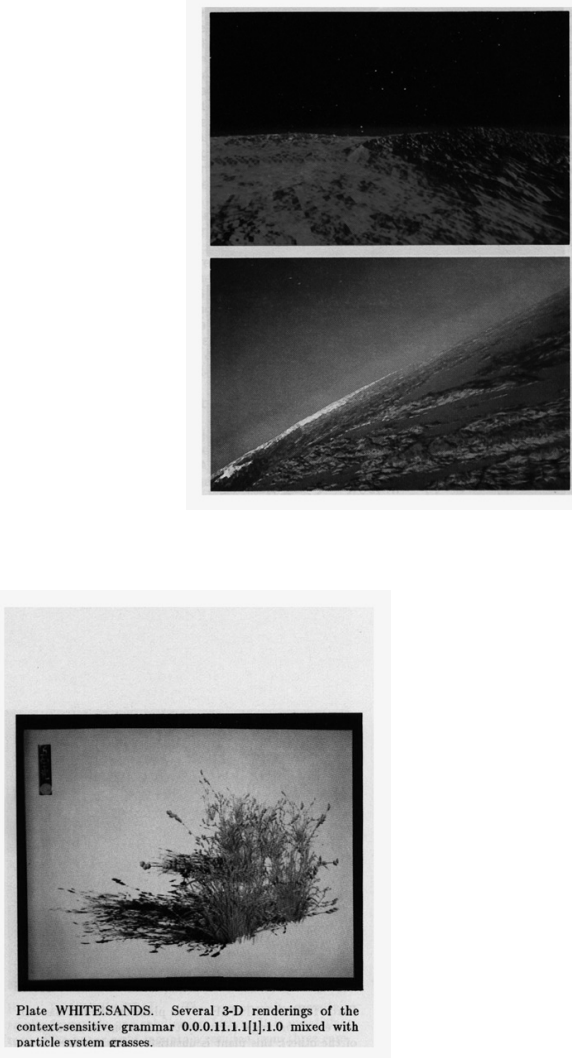

(points, lines, and nodes with particular directions or angles); then these graphs must be given a visual interpretation (a cylinder for a filament or a stem, a disc for a cell, an angle of branching, etc.). Smith's article explains: “The (geometric) trees generated are considered to be data structure maps, not necessarily the final image. A post-processing step, called an interpretation, expands this map, assumed to have only a finite amount of information at each node (finite alphabet), into the final image." 60 It is important to realize that this notion of interpretation refers not only to the replacement of one humanly perceivable geometrical shape by another but to the implementation in a software program of a systematic replacement of one string of symbols for another. This "interpretation" is fully formalistic, but it is created only with reference to what human beings can perceive on a screen or what Hollywood demands appear there. ${ }^{61}$

Smith discusses some of the techniques for going from the discrete representation to the continuous, a process he achieves using a program called GENE (named, presumably, for the biological object, not Gene Rodenberry, creator of Star Trek), which gives the "genotype" (L-system string) a "phenotype" (graphical interpretation) using a variety of established CG techniques (such as anti-aliasing, lighting effects, dropped shadows). Through this process Smith has given the formal languages of Lindenmayer a (new) visual form, a pattern, an interpretation that one can watch on a screen as it unfolds. This interpretation might look like mountains (as in Star Trek II), or it might look like nerve cells (as in Fight Club), or, ironically, it might look, as in the case of the animations of Przemyslaw Prusinkiewicz, like developing plants. 
Prusinkiewicz's 1990 book, written with Lindenmayer and titled The Algorithmic Beauty of Plants, is a beautifully illustrated collection of techniques for producing just such graphical interpretations. The parallels with the work of D'Arcy Wentworth Thompson are highlighted, and it is those common natural forms-the branching tree, the logarithmic spiral of phyllotaxis, the self-similarity of ferns-that repeatedly provides the essential aesthetic pleasure and motivation of the book. In the book Prusinkiewicz develops the "turtle" interpretation for L-systems, a way of formally describing the creation of line segments, or their rewriting, as if created by a tiny turtle who moves in three-dimensional space and can rotate or change direction laterally and is "reading" an L-system as its instructions.

Here, as in all of his published work, Prusinkiewicz gives Alvy Ray Smith credit as the originator of the idea of database amplification and the demonstration of graphical interpretation of L-systems. The fact that Prusinkiewicz chooses to give L-systems a visual form of developing plants might seem obvious - this is after all what L-systems were developed to do. However, Smith's contribution shows that there is no reason inherent in L-systems that would require them to represent plants rather than mountains or neurons. Even if helped along by the original motivation, the connection must still be imagined, as it was in the case of algae/L(G).
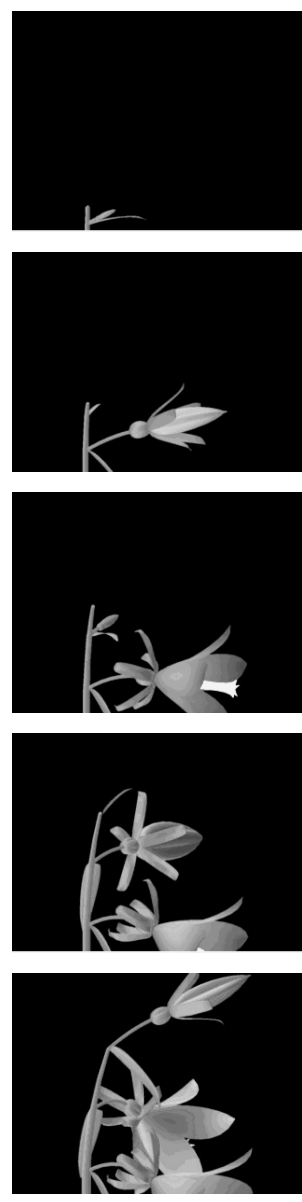

In Prusinkiewicz's films what is made visible is not a plant's imperceptible movement but a theory's. The only way to see the image on the screen is to know why (theoretically) it is there in the first place. Prusinkiewicz is in this way analogous to Ries. When Julius Ries showed his students films of the sea urchin, he forced them to see a particular theory of life-grounded in cell theory, movement, and time-and claimed for it self-evidence. Prusinkiewicz's interpretation forces the viewer to see a theory of biological development (also grounded in cellularity and developmental programs) cleverly disguised as a time-lapse image of a growing plant. The visual form is necessitated only by the perceptual limits, or aesthetic desires, of an observing human being. The rest happens at lightning speed, in the silicon and metal registers of a machine.

\section{Conclusion}

Viewed in the context of a century of visualizing life, the Fight Club opening sequence is an unwitting literalization of Deleuze's "the brain is the screen," 62 an instance of cinema that produces an "image of thought, a visual and acoustic rendering of thought in relation to time and movement." ${ }^{63}$ Reconnecting this 
sequence to a larger historical context of the observation, formalization, and interpretation of life, what becomes evident is its status as animation and the conditions under which its image of the brain may be easily greeted by viewers as alive. It is the result, and a continuation, of the constant confrontation of problems of time, movement, discreteness, and continuity in the life sciences and cinema.

Scientific observation and formal analyses constitute a helical structurewhich, as it unfolds in time, presents more clearly the face of one and then the other. Often in the history of biology the observation of life-the eye-straining, world-denying hard work of observation-is seen as mere prolegomena to an analysis. But the dynamic constraints of visual perception over time are as necessary to the life sciences as the static constraints of formal construction; neverat least never so long as life is understood as a temporal problem-will one triumph over the other. The histological codifications and dictums of nineteenthcentury cell theory were seen to differ in their stillness from the obvious and frenetic facts of living cells kept warm and vital under the lens of a microscope. Static plates and colored preparations representing cell division were rejected as inadequate for the purpose of teaching others to understand, perhaps to believe, the very theory they claimed to prove. At the same time, they became the analytical basis for conceiving of, and then making, time-lapse motion pictures of sea urchin development.

Similarly, L-systems grew from a perceived defect of observations of living things: they lack formal, systematic, or logical coherence-but the theory of Lsystems nonetheless draws fundamentally on the cellularity of observed living things. In turn, the interpretation given to such forms on a computer screen gives rise to new observable forms: brains, mountains, or abstract patterns-patterns in search of a phenomenon, perhaps. Both cell biologists and computer programmers have built machines and media to force a theory of cellularity to become visible-on screen and in time. In these different media the representation of the cell remains central as the connection between stillness and movement, whether as a single-frame image or a symbol occupying a space on a line. It is simultaneously the location and the means by which one becomes many.

At the end of "Plants, Fractals, and Formal Languages," Alvy Ray Smith introduces a strange character: "After the machine has done its work, the artist may step in and modulate the computed form with esthetic judgment, thus becoming the composer of the image." 64 This pathetic and debased artistic genius, reduced to the dial-twisting modulator of aesthetic judgment, looking only at the final pleasing image on the screen, is in our story replaced by the more general category of animator. It is not a question of who is an artist, who a scientist, but of the 
work that generates animation, of the place of that work in the helix of the perceptible and intelligible that continuously twists from microscope to human being to scientific paper to microscope to film camera to textbook to mathematical description to computer program to human being to textbook to graphics workstation to screen to human being.

To quote the poet Rainer Maria Rilke, who also clearly thought through cell theory, we have sought here to follow the cell through its presence in twentiethcentury media as the "tangible immaterial means of representation for everything." Scientific and artistic objects, sea urchin embryos and science fiction mountains, are "realities that emerge from handwork," that of animators tinkering with machines and media. 


\section{Notes}

Thanks to Nicholas King, Kirsten Ostherr, Hajime Nakatani, and Henning Schmidgen for their insights; and to the "Experimentalization of Life" group at the Max Planck Institute for the History of Science, whose invitation to present this material was an important early impetus for the work.

1. Quoted in "Introduction," Rainer Maria Rilke, New Poems: The Other Part, trans. Edward Snow (1908; reprint, New York: North Point Press, 1998), ix.

2. "Interview with Kevin Mack," Fight Club, special ed. DVD, directed by David Fincher (1999).

3. This history should be contrasted with what is by now a much more familiar biological image, that of the gene as program. The rise of molecular biology and the importance of the model of the program to that field are amply documented in Lily Kay, The Molecular Vision of Life: Caltech, The Rockefeller Foundation, and the Rise of the New Biology (New York: Oxford University Press, 1993); Lily Kay, Who Wrote the Book of Life?: A History of the Genetic Code (Stanford: Stanford University Press, 2000); Evelyn Fox Keller, Refiguring Life: Metaphors of Twentieth-Century Biology (New York: Columbia University Press, 1995); and Richard Doyle, On Beyond Living: Rhetorical Transformations of the Life Sciences (Stanford, CA: Stanford University Press, 1997). Our focus here, though concerned in some cases with genetic research and with computer programs, is mostly distinct from this history.

4. Przemyslaw Prusinkiewicz and Martin de Boer, "Obituary: Aristid Lindenmayer (1925-1989)," International Journal of General Systems 18 (1991): 290.

5. That the pictures, inscriptions, traces, and "paper tools" of the laboratory are in their own right generative entities in the production of scientific knowledge has been well documented by historians of science. Ursula Klein, Experiments, Models, Paper Tools: Cultures of Organic Chemistry in the Nineteenth Century (Stanford, CA: Stanford University Press, 2003); and Hans-Jörg Rheinberger, Toward a History of Epistemic Things: Synthesizing Proteins in the Test Tube (Stanford, CA: Stanford University Press, 1997).

6. D.N. Rodowick, Gilles Deleuze's Time Machine (Durham: Duke University Press, 1997), 5. Our investigation was initially inspired by Gilles Deleuze's works on cinema: Cinema 1: The Movement-Image, trans. Hugh Tomlinson (Minneapolis: University of Minnesota Press, 1986); and Cinema 2: The Time-Image, trans. Hugh Tomlinson and Robert Galeta (Minneapolis: University of Minnesota Press, 1989). Some of the original vocabulary of this investigation remains, such as the notions of movement-image and time-image, as well as the notion that philosophy, cinema, biology, and mathematics are mutually engaged in defining concepts related to time, movement, and life.

7. Julius Ries, "Kinematographie der Befruchtung und Zellteilung," Archiv für mikroskopische Anatomie und Entwicklung 74 (1909): 1. Unless otherwise marked, all translations are our own.

8. Ries, "Kinematographie," 1.

9. Ries, "Kinematographie," 2.

10. Julius Ries, "Chronophotographie de la fécondation et de la segmentation," Travaux de l'Association de l'Institut Marey 2 (1910): 225.

11. Ries, "Chronophotographie," 227.

12. Ries, "Kinematographie," 6.

13. Nick Hopwood, "Producing Development: The Anatomy of Human Embryos and the Norms of Wilhelm His," Bulletin of the History of Medicine 74 (2000): 29-79. Hopwood explores the work that went into making these tables, in an argument that sees development as an effect that Wilhelm 
His had to labor to produce.

14. Louise Chevreton and Frederic Vlès, "La cinématique de la segmentation de l'oeuf et la chronophotographie du développement de l'oursin," Comptes rendus hebdomadaires des séances de L'Académie des Sciences 149 (1909): 806.

15. Chevreton and Vlès report that they worked on this film without knowledge that Ries was doing the same thing at the same time. "La cinématique," (1909). Time-lapse imaging of very slow movements had been done well before 1909, by Marey and others, but chronophotographic sequences of images were not made to be projected but to be compared frame by frame or as a static sequence. Thus the films of Chevreton, Vlès, and Ries were among the first that were made for the sole purpose of projection, in order to show accelerated movements of microscopic organisms to the viewer.

16. Efforts were also made to visualize cell division and development by injecting embryos or particular cells of embryos with so-called vital stains that did not kill them, allowing observers to trace the fate of cells over time as development progressed, a technique known as cell lineage studies. See Jane Maienschein, "Cell Lineage, Ancestral Reminiscence, and the Biogenetic Law," Journal of the History of Biology 11 (1978): 129-158; and Charles Galperin, "From Cell Lineage to Developmental Genetics," History and Philosophy of the Life Sciences 20 (1998): 301-350.

17. See Deleuze, Cinema 1, 1-11.

18. Chevreton and Vlès, "La cinématique," 109.

19. Jean Comandon, "Le cinématographie et les sciences de la nature," in Le cinéma, des origins à nos jours, ed. Henri Fescourt (Paris: Éditions de Cygne, 1932), 319.

20. Comandon, "Le cinématographie," 319; emphasis in original.

21. Jean Comandon, "La vie des infiniment petits" (1914), transcript of a lecture given to l'Institut Générale Psychologique, Papers of Jean Comandon, Box Com 1, Pasteur Institute Archives, Paris.

22. Hannah Landecker, "On Beginning and Ending with Apoptosis: Cell Death and Biomedicine," in Remaking Life and Death: Toward an Anthropology of the Biosciences, ed. Sarah Franklin and Margaret Lock, 23-59 (Santa Fe: School of American Research Press, 2003).

23. C.J. Sanderson, "The Mechanism of T Cell Mediated Cytotoxicity. II. Morphological Studies of Cell Death by Time-Lapse Microcinematography," Proceedings of the Royal Society of London. Series B, Biological Sciences, 192 (1976): 244.

24. William R. Clark, Sex and the Origins of Death (Oxford: Oxford University Press, 1996).

25. Pierre Golstein, "Cell Death in Us and Others," Science 281 (1998): 5381.

26. Henri Bergson, Creative Evolution, trans. Arthur Mitchell (New York: Henry Holt, 1911), 165.

27. C.H. Waddington, New Patterns in Genetics and Development (New York: Columbia University Press, 1962), 154; emphasis in original.

28. Waddington, 154.

29. Peter Medawar, Memoirs of a Thinking Radish (Oxford: Oxford University Press, 1986), 63.

30. Woodger began his attempts in the late 1920s and early 1930s. A crucial impetus for him was his translation of Ludwig von Bertalanffy's Modern Theories of Development in 1933. He produced his own work, The Axiomatic Method in Biology, in 1937, predating the more famous attempt by McCulloch and Pitts to model neurons in a similar manner. Woodger's project drew on the assistance of some of the most successful philosophers and theoretical biologists of the twentieth century, without ever seeing much attention. His festschrift Form and Strategy in Science, ed. John R. Gregg and F.T.C. Harris (Dordrecht: D. Reidel Pub. Co., 1964), includes, among others, contributions from 
Popper, Quine, Lewontin, Rashevsky, Bonner, and Lindenmayer.

31. J.H. Woodger, The Axiomatic Method in Biology (London: Cambridge University Press, 1937), $53 \mathrm{ff}$.

32. Woodger's interest seems to have developed from the frozen ground of biology, both literally and figuratively. Trained in zoology and comparative anatomy in England, Woodger took a 1926 term's leave to Vienna to work with Hans Przibram. Unfortunately, the annelids he was supposed to study were "inoperable and the frozen ground could not be induced to yield a further harvest." Gregg and Harris, 3. Instead of lab work, he took to talking with colleagues, and it was here that he was first struck by the frozen and undeveloped language of biological knowledge. Later Woodger would melt into the Cambridge Theoretical Biology Club.

33. Woodger, 15-16.

34. Aristid Lindenmayer, "Life Cycles as Hierarchical Relations," in Form and Strategy in Science, ed. Gregg and Harris, 416-476.

35. It is obvious perhaps only to mid-twentieth-century linguistics and mathematics. The notion of "language" here excludes most of those aspects like ambiguity, hermeneutics, imagistic or poetic language, metaphor or metonymy familiar to the humanities. It is a highly restrictive understanding of language, drawn directly from the description given it in the same era by Chomsky. A "language" here possesses a determinate and specifiable grammar and consists only of the statements that can be produced by that generative grammar-or such is the argument of Chomsky's famous linguistics text Syntactic Structures (The Hague: Mouton, 1957). The technical locus classicus of these ideas is Noam Chomsky, “On Certain Properties of Formal Grammars," Information and Control 2 (1959): 137.

36. The notion of "emergence" that has gained so much attention in the last twenty years might be seen as directly related to this discovery (and to parallel discoveries in other realms of early computing), as a result of the ability to observe a theory in motion. Przemyslaw Prusinkiewicz makes this connection in "Visual Models of Morphogenesis," in Artificial Life: An Overview, ed. Christopher Langton (Cambridge: MIT Press, 1995), 61-74.

37. Laurie Anderson, "New Jersey Turnpike," on disc one of United States Live (Warner Brothers Records, 1984).

38. J.C.R. Licklider, “Interactive Dynamic Modeling," in Prospects for Simulation and Simulators of Dynamic Modeling, ed. George Shapiro and Milton Rogers (New York: Spartan Books, 1967), 282; quoted in M. Mitchell Waldrop, The Dream Machine: J.C.R. Licklider and the Revolution That Made Computing Personal (New York: Viking-Penguin, 2001).

39. The two-part article was called "Mathematical Models for Cellular Interactions in Development (I \& II)," Journal of Theoretical Biology 18 (1968): 280-315.

40. This example is borrowed from Lindenmayer, "Mathematical Models," 284-287. It has been modified by the authors.

41. Word, Language, Grammar, vol. 1 of Handbook of Formal Languages, ed. Arto Salomaa and Grzegorz Rozenberg (Berlin: Springer Verlag, 1997), 254-328. Formal language theory is the strange meeting of mathematics, linguistics, and computer science. Today it is a relatively autonomous branch of set theory, but the initial impetus came from outside mathematics and was taken up as a basis for theoretical computer science in the 1960s to the late 1970s. Three influential papers for this development indicate the diversity and convergence of interests: Chomsky, "On Certain Properties 
of Formal Grammars," 1959; Warren S. McCulloch and Walter Pitts, "A Logical Calculus of Ideas Immanent in Nervous Activity," Bulletin of Mathematical Biophysics 5, no 4 (December 1943): 115-134; and Stephen Kleene, "Representation of Events in Nerve Nets and Finite Automata," in "Automata Studies," vol. 34 of Annals of Mathematics Studies, ed. C.E. Shannon and J. McCarthy (Princeton: Princeton University Press, 1955), 3-42. The formal in formal language theory refers to the fact that its objects-though referred to by the words word, grammar, language-are mathematically formalized through set theory and logic. The various common objects of this field include: machines, abstract machines, automata, grammars, languages, words, alphabets, sequences, symbols, letters, and, occasionally, numbers. A distinction is made between, for example, automata that can "recognize" or "accept" a certain language and grammars that are capable of generating them.

42. R. Baker and G.T. Herman, "Simulation of Organisms Using a Developmental Model: I. Basic Description; II. The Heterocyst Formation Problem," International Journal of Biomedical Computing 3, (1972): 203; emphasis added. R.W. Baker and G.T. Herman, in "CELIA-A Cellular Linear Iterative Array Simulator," in Proceedings of the Conference on Winter Simulation (San Francisco: n.p., 1973), introduced the program CELIA (Cellular Linear Iterative Array). These two papers are the only early papers to publish, in part, the actual software used to implement L-systems. Almost all others are content to publish only the mathematical formalisms or a relevant fragment of the source code or description.

43. The distinction between descriptions of biological matter as continuous or discrete also defines the field of mathematical biology more generally and ties L-systems directly (or at least via the logarithmic spiral of a snail shell) to its spiritual father, D'Arcy Wentworth Thompson. Thompson's attempts to study morphogenesis as a continuous geometrical phenomenon (as well as the reaction-diffusion studies of Turing, Wardlaw, and Bonner) are opposed to a discrete process in which the assumption of cellularity is made primary (as in Lindenmayer's systems). Ironically, the use of L-systems in experimental biology has been tentative and limited; indeed, the liveliest growth was never in experimental biology but rather in computer science and mathematics itself. See Evelyn Fox Keller, Making Sense of Life: Explaining Biological Development with Models, Metaphors, and Machines (Cambridge: Harvard University Press, 2002).

44. Grzegorz Rozenberg and Arto Salomaa, "When L Was Young," in The Book of L, ed. Rozenberg and Salomaa (Berlin: Springer Verlag, 1986), 383.

45. John von Neumann, Theory of Self-Reproducing Automata, ed. Arthur Burks (Urbana: University of Illinois Press, 1966).

46. McCulloch and Pitts.

47. Kleene.

48. Stanislaw M. Ulam, "On Some Mathematical Problems Connected with Patterns of Growth of Figures," in Mathematical Problems in the Biological Sciences (Proceedings of Symposia in Applied Mathematics) (Providence: American Mathematical Society, 1962), 215-224.

49. Seymour Ginsburg, An Introduction to Mathematical Machine Theory (Reading, MA: Addison Wesley Pub. Co., 1962).

50. In the early days of L-systems, approaches always stressed the biological interpretation. G.T. Herman and G. Rozenberg, Developmental Systems and Languages (New York: North Holland Publishing Company, 1975) devote thirty or more pages of the introduction and three of their eighteen chapters to discussing the biological uses of L-systems. Among the topics they treat are the 
so-called Firing Squad Synchronization Problem, pigmentation in shell patterns, polarity, and the French Flag problem. It also ends with a charming exercise: "18.1. Go out to a nearby field. Pick a flower. Simulate its development" (341). Other widely cited early papers that explicitly use L-systems in biological experimentation include V. Surapipith and A. Lindenmayer, "Thioguanine-Dependent Light Sensitivity of Perithecial Initiation in Sordaria fimicola," Journal of General Microbiology 57 (1967): 227-237; D. Frijters, "Principles of Simulation of Inflorescence Development," Annals of Botany 42 (1978): 549-560; and A.D. Bell, "Branching Patterns: The Simulation of Plant Architecture," Journal of Theoretical Biology 81 (1979): 351-375. However, despite these attempts, the most vibrant interest in L-systems (due to their formal nature) came from outside biology. Rozenberg and Salomaa stress the veritable formal bestiary of L-systems that has developed along with a taxonomic classification that puts other mathematical nomenclatures to shame (254).

51. Lindenmayer, "Mathematical Models for Cellular Interactions," 284.

52. Brian Goodwin, "The Division of Cells and the Fusion of Ideas," in Towards a Theoretical Biology, ed. C.H. Waddington (Edinburgh: Edinburgh University Press, 1968).

53. A. Lindenmayer, J. Kelemen, and A. Kelemenova, "Interview on the Origins and Development of the Theory of L-systems," Bulletin of the European Association for Theoretical Computer Science 23 (1984): 185-198.

54. Bergson, 89.

55. See especially, Stefan Helmreich, Silicon Second Nature: Culturing Artificial Life in a Digital World (Berkeley and Los Angeles: University of California Press, 1998); and Richard Doyle, On Beyond Living: Rhetorical Transformations of the Life Sciences (Stanford: Stanford University Press, 1997), 109ff.

56. Or any number of other things, as in, e.g., Yoav I. Parish and Pascal Muller, "Procedural Modeling of Cities" (paper presented at ACM SIGGRAPH, Los Angeles, 12-17 August 2001); or Gregory S. Hornby and Jordan B. Pollack, "Body-Brain Coevolution Using L-Systems as a Generative Encoding," in GECCO 2001: Proceedings of the Genetic and Evolutionary Conference, ed. Lee Spector and Eric Goodman (San Francisco: Morgan Kaufmann, 2001), 600.

57. Here the formalism used was not L-systems but a technically similar method for rewriting graphs, in this case, a system for rewriting graphs which are in interpreted as triangles. Alvy Ray Smith, "The Genesis Demo: Instant Evolution with Computer Graphics," American Cinematographer 63, no. 10 (October 1982): 1038, 1048-1050.

58. Alvy Ray Smith, “George Lucas Discovers Computer Graphics,” IEEE Annals of the History of Computing 20, no. 2 (1998): 48-49.

59. Alvy Ray Smith, "Plants, Fractals, and Formal Languages," ACM Computer Graphics 18, no. 3 (July 1984): 6.

60. Smith, "Plants, Fractals, and Formal Languages," 2.

61. Compare with Friedrich Kittler, "Computer Graphics: A Semi-Technical Introduction,” Grey Room 2 (Winter 2001): 30-45.

62. See "The Brain Is the Screen: An Interview with Gilles Deleuze," in The Brain Is the Screen: Deleuze and the Philosophy of Cinema, ed. Gregory Flaxman (Minneapolis: University of Minnesota Press, 2000).

63. Rodowick, 6 .

64. Smith, "Plants, Fractals, and Formal Languages," 6. 
Copyright of Grey Room is the property of MIT Press and its content may not be copied or emailed to multiple sites or posted to a listserv without the copyright holder's express written permission. However, users may print, download, or email articles for individual use. 